\title{
PEMBERDAYAAN EKONOMI MASYARAKAT MELALUI PROGRAM PELATIHAN PEMBUATAN PIZZA PADA ANGGOTA PKK DAWUHAN KABUPATEN SITUBONDO
}

\author{
Anik Sudarismiati ${ }^{1)}$; Muhammad Yusuf Ibrahim ${ }^{2)}$ \\ anik.sudarismiati@gmail.com ${ }^{1)}$ \\ Universitas Abdurachman Saleh Situbondo
}

\begin{abstract}
Abstrak : Program Kesejahteraan Keluarga atau yang biasa disebut PKK merupakan langkah awal untuk menuju peningkatan kesejahteraan masyarakat khususnya Kelompok PKK RT.001 RW.002 Kelurahan Dawuhan Kabupaten Situbondo. Disamping itu perlu adanya program yang mampu untuk meningkatkan wawasan, keterampilan, dan pengalaman guna mewujudkan program tersebut. Beberapa permasalahan yang dihadapi oleh Kelompok PKK RT.001 RW.002 Kelurahan Dawuhan diantaranya rendahnya kreatifitas dan pengalaman membuat produk produk makanan yang bernilai ekonomis. Setelah sebelumnya diberikan pelatihan pembuatan abon ikan tongkol dan pembuatan sosis ayam, maka diharapkan dapat melanjutkan untuk bisa membuat produk olahan kembali yang lebih baik yaitu Pizza. pendapatan anggota PKK dan masyarakat masih minim, program peningkatan kesejahteraan keluarga masih belum terlaksana, program pokok PKK Kabupaten Situbondo dalam bidang pendidikan dan keterampilan masih sedikit. Solusi yang ditawarkan atas permasalahan tersebut dalam program pemberdayaan ekonomi masyarakat melalui program pelatihan pembuatan Pizza pada anggota PKK Dawuhan Kabupaten Situbondo diantaranya menciptakan produk baru yang lebih bernilai ekonomis yaitu Pizza yang gurih dan nikmat, dengan bahan-bahan yang bebaa dari bah kimia seperti halnya produk pizza yang banyak dijual di masyarakat dan memberikan pengalaman ilmu dan teknik produksi pizza yang lebih efektif dan efisien. Kegiatan dilanjutkan dengan pelatihan manajemen diantaranya pemasaran, hukum bisnis, produksi dan keuangan UMKM serta dilakukanevaluasi hasil kegiatan.

Kata Kunci : Pemberdayaan Ekonomi, Pizza, PKK
\end{abstract}

\section{PENDAHULUAN}

Kelurahan Dawuhan terdiri dari beberapa ibu-ibu yang tergolong dalam kelompok Program Kesejahteraan Keluarga (PKK) yaitu PKK RT.001 RW.002 Kelurahan Dawuhan Kabupaten Situbondo, Setiap tahunnya ada banyak kegiatan-kegiatan yang dilakukan untuk meningkatkan wawasan, keterampilan, dan pengalaman guna meningkatkan taraf hidup keluarga pada khusunya dan masyarakat pada umumnya seperti diadakannya seminar-seminar pemberdayaan ekonomi keluarga. 
Sesuai dengan program dasar PKK yaitu penghayatan dan pengamalan pancasila, gotong royong, pangan, sandang, perumahan dan tatalaksana rumah tangga, pendidikan dan keterampilan, kesehatan, pengembangan kehidupan berkoperasi, kelestarian lingkungan hidup, perencanaan sehat. Dimana semua program tersebut harus didasari dengan kemampuan dan pengalaman bagaimana secara tindakan nyata mampu untuk meningkatkan keluarga masing-masing.

Salah satu kegiatan pengabdian pada masyarakat yang diajukan ini adalah memberikan pelatihan-pelatihan berupa pembuatan olahan makanan yaitu Pizza. Sebelumnya kelompok PKK dawuhan telah diberikan pelatihan berupa pembuatan produk Sosis berbahan dasar daging Ayam Potong, Kemudia juga telah diberikan pelatihan produk Abon dari bahan daging Ikan Tongkol.

Inovasi produk selanjutnya yang yaitu membuat produk pizza. Jika dilihat dari segi peluang pasar, produk ini sangat menjanjikan untuk bisa dijadikan bisnis rumah tangga, produk yang terjual di beberapa toko di Situbondo mayoritas berbahan pengawet yang tentu dapat berdampak bagi kesehatan konsumennya. Adanya bahan-bahan kimia berbahaya, kandungan pengawet yang pasti digunakan mengakibatkan banyak permasalahan penyakit bagi masyarakat yang mengkonsumsinya dan akan berbalik dengan hasil manfaat yang seharunya memberikan gizi makanan yang baik bagi masyarakat.

\section{Permasalahan Mitra}

\section{PKK RT.001 RW.002 Kelurahan Dawuhan}

PKK RT.001 RW.002 Kelurahan Dawuhan Kabupaten Situbondo merupakan mitra pertama yang menjadi sasaran pelaksanaan pemberdayaan ekonomi masyarakat melalui pelatihan pembuatan pizza. Beberapa permasalahan yang dialami pada umumnya bagi anggota PKK ini diantaranya :

a. Rendahnya Kreatifitas dan Pengalaman Menciptakan Produk Pizza yang berbahan dasar sosis dan abon ikan. Langkah yang utama untuk memberikan solusi permasalahan tersebut adalah meningkatkan kemampuan dan kreatifitas ibu-ibu Kelompok PKK RT.001 RW.002 Kelurahan Dawuhan Kecamatan Situbondo dalam membuat produk pizza. Bagi ibu-ibu Anggota PKK Kelurahan dawuhan masih minim. Hal ini menjadi peluang, mengingat 
bahwa Wilayah Kabupaten Situbondo ini menjadi peluang untuk memasarkan produk olahan rumah tangga karena lokasi dekat dengan pasar yang mudah diakses masyarakat serta minimnya industri olahan makanan. Secara tidak langsung pendapatan masyarakat hanya tergantung pada sektor perkebunan/pertanian, hasil tangkapan ikan dan sektor jasa lainnya.

b. Pendapatan anggota PKK Masih Sedikit

Pendapatan masyarakat tergantung pada bagaimana sebuah keluarga bisa menemukan peluang bisnis yang bisa menunjang ekonomi keluarga, hal ini bisa terjadi apabila adanya keterlibatan oleh ibu-ibu rumah tangga khususnya anggota PKK Kelurahan Dawuhan untuk bisa membuat suatu produk yang dapat memberikan keuntungan ekonomi. Dalam program pengabdian masyarakat kali ini yang menjadi perhatian utama adalah bagaimana dari pengalaman ibu-ibu anggota PKK yang diperoleh selama mengikuti pelatihan pembuatan pizza ini bisa menjadi usaha-usaha baru di masyarakat dan kemudian terus berkembang, dalam hal ini tentunya bisa meningkatkan pendapatan keluarga serta membuka lapangan pekerjaan baru di masyarakat khususnya di Kelurahan Dawuhan, Kecamatan Situbondo

c. Program peningkatan kesejahteraan keluarga masih belum terlaksana dengan baik. Melalui keterampilan dan kemampuan dalam berwirausaha, masyarakat tidak akan bingung memikirkan ekonomi keluarga. Dengan tercukupinya kebutuhan melalui hasil yang diperoleh dari penjualan olahan makanan pizza ini maka kesejahteraan keluarga akan semakin baik dan terjamin, karena permasalahan yang biasa menjadi faktor utama rendahnya kesejahteraan keluarga karena adanya faktor keterbatasan ekonomi yang berimbas secara langsung pada harmonisasi keluarga tersebut. Diharapkan dengan dimilikinya ilmu pembuatan pizza ini dapat menambah pengalaman dan kemampuan untuk mengembangkan usahanya dan nantinya akan terwujud keluarga yang sejahtera .

d. Program pokok PKK RT.001 RW.002 Kabupaten Situbondo dalam bidang pendidikan dan keterampilan masih sedikit, program yang hanya dikonsep tanpa pelaksanaan kerja tidak mungkin terwujud tanpa adanya tindakan berupa kegiatan yang bisa menambah pengetahuan, salah satunya yaitu 
pelatihan-pelatihan yang bisa memberikan perubahan pola fikir bagi seluruh anggota PKK khusunya kelompok PKK RT.001 RW.002 Kelurahan Dawuhan. Dengan kegiatan pelatihan-pelatihan yang diberikan dari proses pengolahan hingga menjadi produk rumah tangga yang siap untuk dijual ke pasar, maka secara pasti anggota PKK benar-benar telah memberikan kontribusi besar atau memberikan peranan yang baik dalam upaya meningkatkan kesejahteraan keluarga Indonesia.

\section{Usaha Makanan Rumahan (Penghasil Sosis dan Abon)}

Usaha Sosis Ayam dan Abon ikan juga mulai berkembang setelah sebelumnya diadakan program pemberdayaan ekonomi keluarga melalui pelatihan sosis dan abon, sehingga mulai bermunculan usaha tersebut di lingkungan dawuhan, produk yang dihasilkan tersebut kemudian akan diinovasikan menghasilkan produk baru yang lebih inovatif yaitu Pizza. Beberapa permasalahan yang dihadapi oleh Usaha Ayam Potong Mimbaan diantaranya:

1) Persediaan bahan Sosis dan Abon Cukup Signifikan

Persediaan bahan Sosis dan Abon melimpah dan terkadang banyak sisa setiap harinya yang tidak terjual akibat fluktuasi permintaan konsumen. Hal ini tentunya dikarenakan kurangnya inovasi para konsumen untuk mengolah menjadi beberapa jenis makanan lainnya.

2) Penjualan produk jenis sosis maupun abon masih sedikit untuk diminati sehingga jika dibuat produk yang lebih inovatif menjadi Pizza bisa lebih menarik minat konsumen.

3) Variasi olahan sosis dan abon masih rendah

Hal ini dikarenakan banyaknya masyarakat yang masih tergantung pada makanan olahan pabrik. Tanpa mempertimbangkan dampaknya yang cukup berbahaya bagi kesehatan karena mengandung kimia atau pengawet. Kebutuhan kue Pizza menjadi produk yang cukup digemari masyarakat Situbondo, jika dilihat penjualan beberapa toko roti mulai menampilkan produk pizza di etalase produknya dengan penjualan yang mengalami peningkatan setiap harinya. 


\section{SOLUSI DAN TARGET LUARAN}

Berdasarkan beberapa permasalahan diatas maka melalui program Pemberdayaan Ekonomi Masyarakat ini diharapkan bisa membantu menjawab tantangan yang ada. Anggota PKK Dawuhan ini nantinya akan diberikan pelatihan-pelatihan untuk memberikan Solusi atas permasalahan tersebut diantaranya dengan beberapa pelatihan yaitu :

1. Pelatihan 1, Pelatihan Membuat Pizza

2. Pelatihan 2, Pelatihan Pemasaran

3. Pelatihan 3, Pelatihan Hukum Bisnis

4. Pelatihan 4, Pelatihan keuangan

5. Pelatihan 5, Pelatihan Manajemen Sumberdaya Manusia

Proses pembuatan produk pizza ini sangatlah mudah, dengan inovasi bahan baku yang baru yaitu dengan tambahan sosis dan abon ikan tongkol akan memberikan ciri khas masakan yang bermuatan lokal. Situbondo sebagai daerah pesisir akan menopang bahan baku produk pizza ini. Produk pizza yang akan dilatihkan ini merupakan hasil olahan dengan proses yang aman serta hasil produknya yang gurih serta nikmat. Bebas dari bahan pengawet serta memiliki beberapa varian rasa merupakan salah satu keunggulannya dan bisa menjadi peluang usaha baru dimasyarakat .

\section{METODE PELAKSANAAN}

Metode Pelaksaan Pemberdayaan Ekonomi Masyarakat Melalui Program Pelatihan Pembuatan Pizza Pada Anggota PKK Dawuhan Kabupaten Situbondo adalah sebagai berikut : 


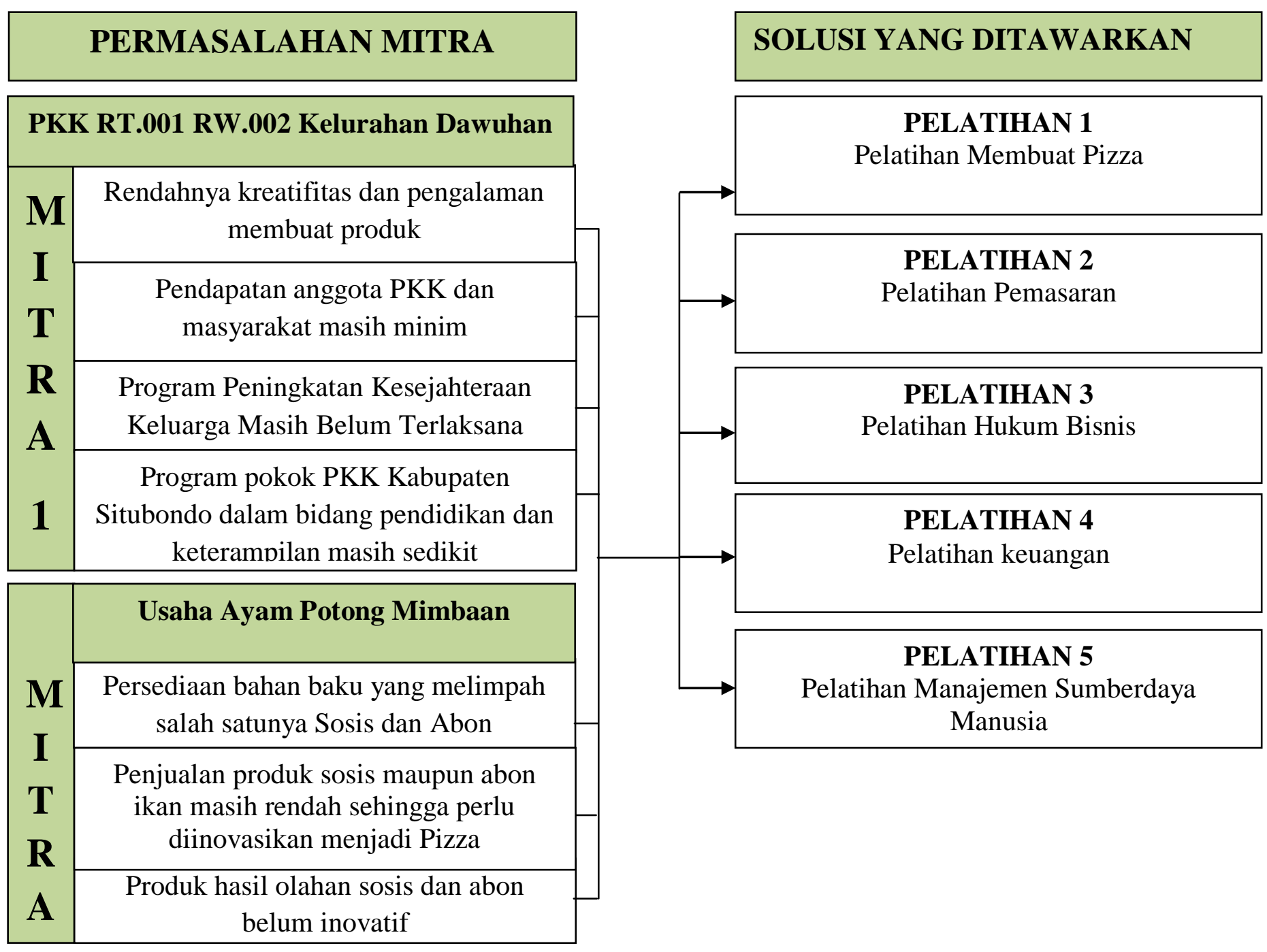

\section{HASIL DAN LUARAN YANG DICAPAI}

\section{Hasil Pelaksanaan Kegiatan}

Hasil pelaksanaan kegiatan Program Kemitraan Masyarakat (PKM) dilaksanakan melalui pemberian materi dan pelatihan-pelatihan, kegiatan dilaksanakan dengan baik dan lancar. Pelaksanaan pelatihan dilaksanakan melalui metode tatap muka dengan metode ceramah dan demonstrasi, dilanjutkan dengan pelatihan/praktek langsung untuk membuat produk Pizza. Kegiatan ini dilaksanakan selama bulan Juni s.d Agustus 2018 dan dilaksanaan di Ketua Kelompok PKK Dawuhan yaitu Ibu. Endang Luluk Mutiara di lingkungan DAM RT 01 / RW 02 Kelurahan Dawuhan, Kecamatan Situbondo. 


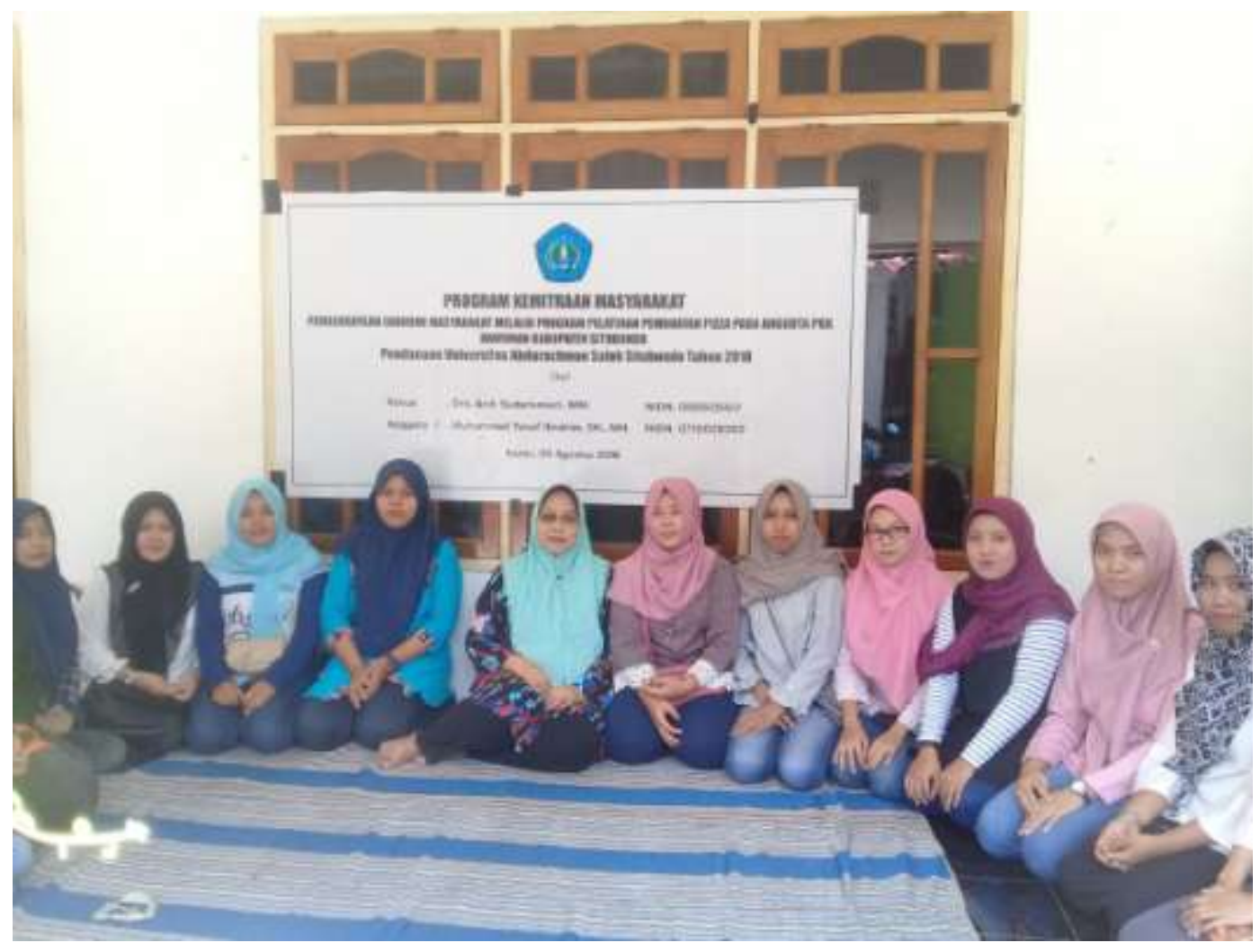

Gambar 1. Foto Bersama dengan Anggota PKK Dawuhan

Pelaksanaan kegiatan pelatihan pembuatan Pizza ini diikuti oleh 10 anggota PKK aktif dengan pokok bahasan dan pelatihan meliputi :

1. Pelatihan dan Bimbingan Teknis

2. Pelatihan Teori Pemasaran

3. Pelatihan Teori Hukum Bisnis

4. Pelatihan Teori Manajemen keuangan UMKM

Pelatihan ini dimaksudkan agar ibu-ibu Kelompok PKK Dawuhan mampu mempraktekkan proses pembuatan pizza dengan menggunakan bahan baku yang ada di pasar, khususnya di Kabupaten Situbondo, disamping itu kegiatan ini diharapkan mampu memberikan ilmu untuk mengambangkan usaha mitra. Dalam pelatihan ini juga diajarkan bagaimana membuat inovasi produk pizza menjadi produk-produk olahan lainnya yang mampu bersaing di pasar. Melalui pelatihan ini juga, mitra yang terkait yaitu Anggota PKK RT.001 RW.002 Kelurahan 
Dawuhan dan Usaha Makanan Rumahan bisa belajar tentang tata cara membuat makanan yang sehat dan higienis.

Makanan sehat dan higienis menjadi sorotan masyarakat, ditengah banyaknya jenis jajanan anak-anak. Masyarakat mandiri sangat konsen tentang jajanan sehat untuk anak. Maraknya jajanan anak yang menggunakan bahan kimia berbahaya memang cukup meresahkan khususnya Ibu-ibu. Berbagai himbauan dan razia yang di lakukan oleh pihak berwenang tidak membuat para pedagang jera. Oleh sebab itu perlunya dilakukan penyadaran, salah satunya dengan model pemberdayaan. Dalam proses pemberdayaan yang dilakukan tidak hanya sekedar masalah permodalan namun juga penyuluhan, pelatihan dan pendampingan secara intensif.

\section{Pelatihan dan Bimbingan Teknis Membuat}

Keterbatasan waktu pertemuan mengakibatkan tidak semua materi dapat disampaikan secara menyeluruh. Pelaksanaan kegiatan pengabdian diawali pada tangga 10 Agustus 2017 dengan kegiatan awal yaitu pemberian bimbingan teknis/pelatihan kepada anggota PKK yaitu membuat Pizza. Tahap tahap pelaksanaan bimtek ini diantaranya :

\section{a. Pemberian bahan-bahan berikut :}

Bahan untuk roti :
1) Tepung terigu protein sedang $1 / 2 \mathrm{~kg}$
2) Fermipan 5 gr
3) Minyak sayur $3 \mathrm{sdm}$
4) Garam $1 / 2 \mathrm{sdt}$
5) Gula pasir $2 \mathrm{sdm}$
6) Air $250 \mathrm{ml}$ 


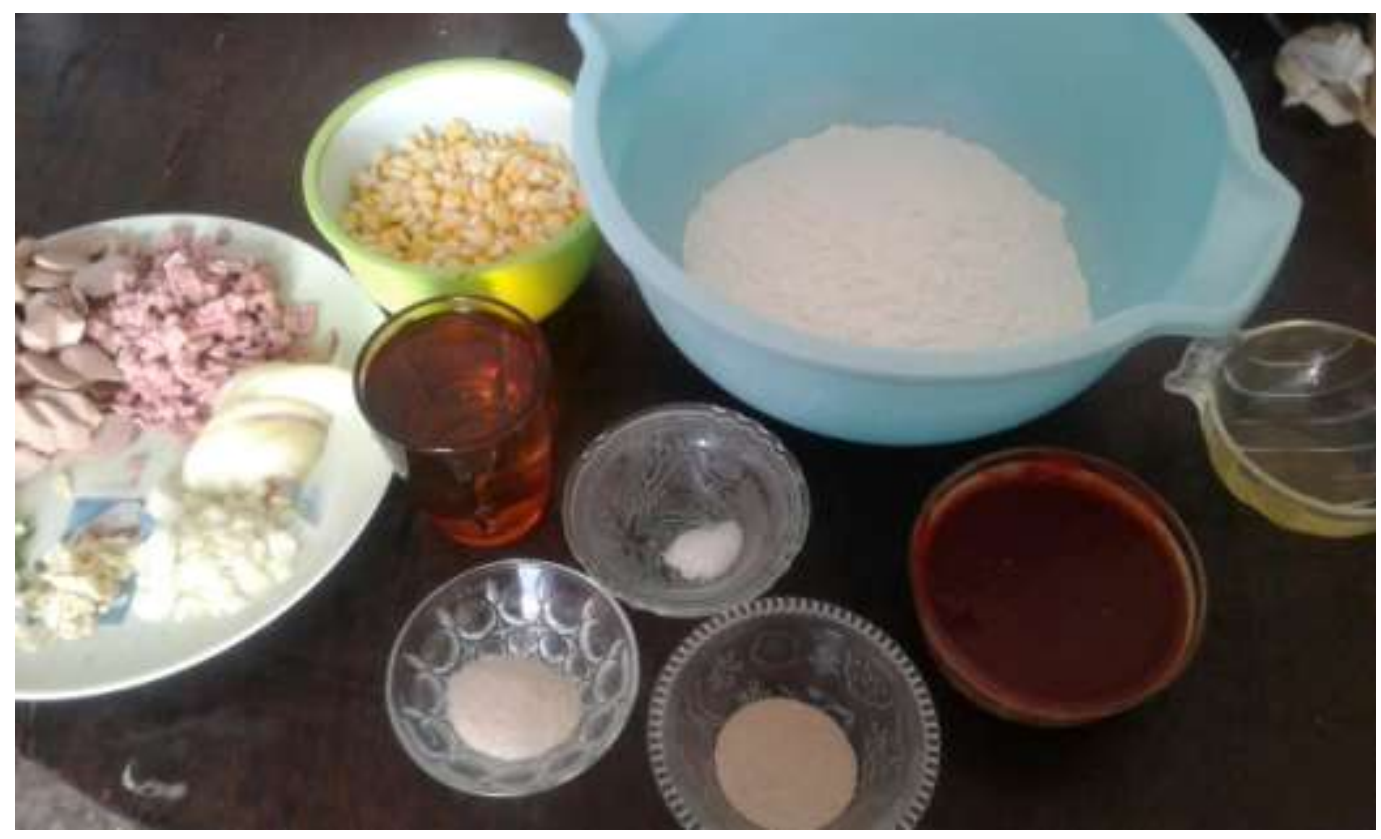

Gambar 2. Bahan-bahan Pizza

Bahan untuk topping :

1) Saus tomat

2) Keju mozarela (dipotong-potong)

3) Bawang bombay (dicincang halus)

4) Topping diantaranya ikan tuna, sosis, bakso, daging asap, ayam, Abon.

\section{b. Persiapan Bahan sebelum melakukan praktik pembuatan pizza :}

1) Siapkan wajan teflon, kemudian panaskan dan cairkan $1 \mathrm{sdm}$ mentega.

2) Letakkan adonan pizza diatas wajan, taburi dengan keju mozarella.

3) Selama memasak, tutupilah wajan dengan penutupnya, agar benarbenar matang dan keju mencair dengan sempurna.

4) Pizza teflon siap dihidangkan. 


\section{c. Proses pelatihan pembuatan Pizza}

Anggota PKK dawuhan melanjutkan kegiatan pembuatan pizza, setelah bahan dan perlengkapan disiapkan, maka proses selanjutnya adalah :

1) Adonan dikempiskan, kemudian takar dan bagi adonan menjadi @ 10 gram perbiji.

2) Bentuk adonan pizza menjadi bulat, lalu diamkan selama 10 menit.

3) Gilas adonan pizza menjadi berbentuk bulat dan pipih.

4) Siapkan loyang, lalu oleskan margarin di permukaannya. Letakkan adonan.

5) Gunakan garpu untuk menusuk-nusuk permukaan adonan kulit pizza

6) Oleskan bahan saus di permukaan kulit pizza.

7) Taburkan topping : keju, sosis, abon dan tumisan ayam yang telah dicincang.

8) Masukkan ke dalam oven dan panggang dengan suhu sekitar 190 derajat Celsius, tunggu selama 7 menit hingga keju mencair.

9) Pizza mini siap dihidangkan.

Hasil pizza yang telah diolah akan seperti berikut :

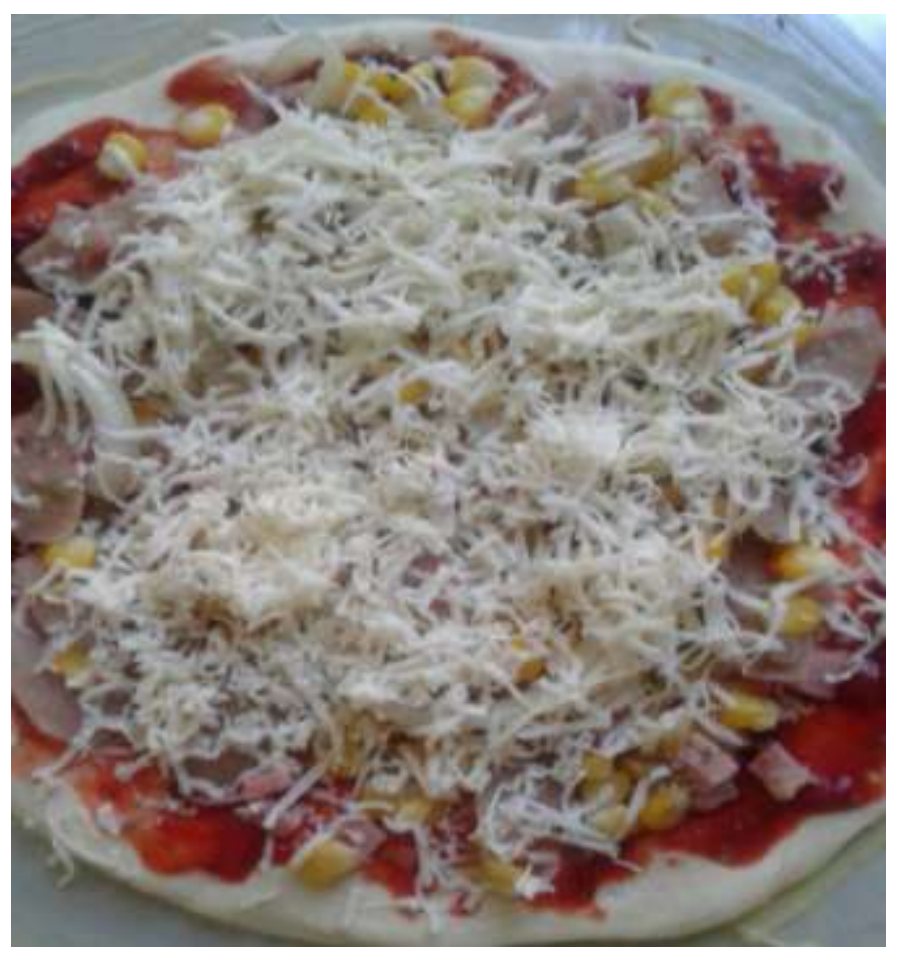

Gambar 3. Hasil produk pelatihan 
Trend penjualan produk pizza menjadi sangat populer saat ini, tidak hanya di Kabupaten Situbondo namun juga di beberapa daerah sekitar seperti Kabupaten Banyuwangi dan Jember, tingginya selera masyarakat atas produk makanan khas barat ini kemudian mendorong para pelaku usaha makanan membuat produk jenis ini. Selain bahan baku yang sangat melimpah namun juga proses pembuatan yang mudah diharapkan mampu memberikan pengalaman pembuatan makanan ini dari proses awal hingga selesai. Setelah praktek pembuatan pizza selesai, tepatnya pada tanggal 15 Agustus 2018 juga berlangsung pelatihan manajemen lainnya, diantaranya pemasaran, hukum bisnis, produksi dan keuangan UMKM serta dilakukan evaluasi hasil kegiatan.

\section{Pelatihan Teori Manajemen Produksi dan Keuangan}

Materi yang diberikan yaitu mengenai pengelolaan manajemen usaha mikro yaitu proses produksi dan keuangan, permasalahan yang sering terjadi bagi usahausaha kecil yang dimasyarakat juga menjadi pembahasan dalam pelatihan ini sebagai pedoman untuk meningkatkan jumlah wirausaha baru dan peningkatan pendapatan pendapatan masyarakat khususnya ibu-ibu anggota PKK di Kelurahan Dawuhan Situbondo. Minimnya pengetahuan tentang proses pembuatan produk pizza merupakan permasalahan yang paling utama, dengan dilaksanakannya praktek langsung membuat pizza ini,. Disamping itu kemudian para anggota juga dibekali bagaimana mengelola bahan baku agar efektif dan efisien nantinya bisa memiliki kesiapan yang bagus untuk memulai usaha ini.

Kegiatan ini diharapkan mampu untuk meningkatkan penjualan makanan pizza di Kabupaten Situbondo sehingga bisa meningkatkan pendapatan keluarga dan menjadi industri rumah tangga yang handal dan dapat terus dikembangkan. Materi keuangan diarahkan untuk mengetahui tentang sumber permodalan usaha serta seberapa besar permodalan yang dibutuhkan untuk usaha tersebut, setelah mengetahui prosesnya maka para ibu-ibu PKK akan mampu untuk memulai manajemen usaha yang mandiri serta mampu mencatat keuangannya dari segi besar biaya dan pendapatan yang diperoleh untuk mengetahui apakah usahanya akan untung maupun rugi. 
Anggota PKK juga diberikan pemahaman tentang manfaat permodalan sendiri maupun permodalan melalui pinjaman bank, saat ini pemerintah gencar untuk menyalurkan bantuan permodalan berupa pinjaman dengan bunga murah, sehingga bisa dimanfaatkan bagi para pelaku usaha baru yang ingin mengembangkan usahanya.

\section{Pelatihan Pemasaran dan Hukum Bisnis}

Pelatihan tahap ini materi yang diberikan tentang pemasaran usaha dan bentuk-bentuk badan hukum serta persyaratan-persyaratan untuk pendiriannya. Manfaat yang bisa diambil oleh anggota PKK Kelurahan Dawuhan tersebut dalam pemasaran diantaranya :

1. Model produk, yaitu bagaimana model suatu produk agar menarik perhatian konsumen untuk membelinya, hal yang terkandung dalam model ini termasuk bentuk pizza yang inovatif menjadi beberapa macam bentuk terbaru atau berbeda dengan yang lainnya. Disamping itu aneka rasa pizza bisa dimodifikasi manjadi beberapa macam sesuai selera konsumen.

2. Harga jual produk, yaitu dengan menyesuaikan antara total biaya produksi dan laba yang direncanakan maka akan mengetahui harga jual produk yang sesungguhnya kemudian untuk menjadi pertimbangan apakah harga yang ditawarkan bisa bersaing di pasar atau tidak. Harga jual produk pizza ini antara Rp. 20.000 hingga Rp. 50.000 per satu produk.

3. Promosi, yaitu langkah untuk memperkenalkan produk kepada masyarakat. Langkah pemanfaatan tekhnologi adalah yang paling tepat, media pemasaran online sangat membantu untuk mempercepat proses pemasaran produk. Beberapa cara pemasaran yang diajarkan diantaranya yaitu dengan media sosial facebook, Instagram, Whatsapp. Sedangkan media untuk bertransaksi, anggota PKK diberikan pemahaman membuka toko online di Bukalapak, tokopedia dan shopee.

4. Distribusi, yaitu bagaimana membuat produk bisa sampai pada konsumen, penjualan bisa dengan cara direct selling atau penjualan langsung dan bisa juga dengan agen. Langkah-langkah pengenalan produk dengan cara langsung tersebut merupakan hal yang paling mudah untuk dilaksanakan 
bagi usaha-usaha di masyarakat yang kemudian akan semakin dikenal dan diminati oleh masyarakat banyak. Jika menggunakan media penjualan online maka jasa pengiriman dibutuhkan seperti JNE, J\&T dan Pos Indonesia.

Setelah semua pelatihan selesai para Ibu-ibu anggota PKK lingkungan Dam Kelurahan Dawuhan Kecamatan Situbondo dapat mencoba mempraktekkan usaha tersebut dirumahnya, diharapkan berawal dari mengetahui proses pembuatannya, kemudian timbul keinginan membuat kembali produk makanan tersebut kemudian bisa memasarkannya. Nantinya bisa membuka lapangan pekerjaan baru di masyarakat dimasa mendatang.

\section{Evaluasi Kegiatan}

Kegiatan evaluasi dilaksanakan sebagai monitoring atas hasil yang dicapai atas beberapa kegiatan sebelumnya apakah terdapat kendala yang dihadapi masing-masing anggota PKK dawuhan dalam melaksanakan proses produksi dan langkah untuk memulai usahanya. Kegiatan evaluasi ini sangat bermanfaat untuk mengukur kemampuan masing-masing anggota dalam menyerap sehingga mempermudah proses pendampingan pada tahap berikutnya.

\section{Luaran Yang Dicapai}

Berikut luaran yang telah dicapai atas Program Kemitraan Masyarakat (PKM) ini yaitu :

1. Meningkatnya pengetahuan, kemampuan, pengalaman dan kreatifitas ibuibu Kelompok PKK RT.001 RW.002 di Kelurahan Dawuhan dalam membuat produk pizza, dimana sebelumnya anggota PKK dawuhan ini masih belum mengetahui bagaimana proses pembuatannya hingga siap untuk dikonsumsi dan dijual, dengan pelatihan ini pengalaman peserta semakin bertambah serta dapat menerapkan ilmunya di rumah.

2. Peluang untuk meningkatkan pendapatan ibu-ibu Kelompok PKK sangat besar, Setelah memahami proses pembuatan hingga selesai, akan muncul ketertarikan untuk menjual produk ini ke masyarakat. Kesukaan terhadap 
produk olahan ini merupakan modal utama dalam melanjutkan usahanya, penjualan yang diawali dari sedikit demi sedikit kemudian diharapkan menjadi terus berkembang dengan dukungan pemasaran online.

3. Peluang mendirikan usaha baru dalam makanan ini sangat besar dan mampu memberikan tambahan pendapatan bagi anggota PKK Dawuhan dikemudian hari karena selain prosesnya yang mudah, bahan baku yang mudah didapat, serta jarangnya produk pizza yang dipasarkan oleh produsen lainnya.

4. Meningkatnya kesejahteraan keluarga Kelompok PKK dan masyarakat pada umumnya. Hal ini bisa diukur dari jumlah penjualan yang terjual ke pasar. Hasil laba yang diperoleh akan berhubungan langsung dengan pemenuhan kebutuhan keluarga sehingga tingkat kesejahteraan keluarganya semakin meningkat

5. Terwujudnya 10 program pokok PKK Kabupaten Situbondo yaitu Pendidikan dan Keterampilan, kegiatan ini juga merupakan salah satu kegiatan pokok yang wajib untuk dilaksanakan, sebagai organisasi kemasyarakatan yang memberdayakan wanita untuk turut berpartisispasi dalam pembangunan indonesia. Semakin banyak anggota PKK yang berpengalaman dalam membuat produk bernilai ekonomis, maka akan semakin bisa menggali kreatifitasnya untuk dijadikan sebuah peluang bisnis yang menjanjikan.

\section{KESIMPULAN DAN SARAN}

\section{A. Kesimpulan}

Program Kemitraan Masyarakat (PKM) ini bermanfaat khususnya Bagi ibuibu Kelompok PKK RT.001 RW.002 Kelurahan Dawuhan dalam upaya peningkatan jiwa wirausaha, Luaran yang dicapai dari kegiatan pengabdian ini adalah pertama meningkatnya pengetahuan, kemampuan, pengalaman dan kreatifitas Ibu-ibu kelompok, kedua peluang untuk meningkatkan pendapatan ibuibu Kelompok PKK sangat besar melalui membuka usaha olahan makanan khususnya prodk pizza. Ketiga yaitu meningkatnya kesejahteraan keluarga Kelompok PKK dan masyarakat pada umumnya dan keempat terwujudnya 10 
program pokok PKK Kabupaten Situbondo. Diharapkan atas dilaksanakannya program pemberdayaan ekonomi keluarga ini mampu meningkatkan kesejahteraan keluarga di masyarakat.

\section{B. Saran}

Saran yang bisa diberikan atas pelaksanaan Program Kemitraan Masyarakat (PKM) kepada ibu-ibu Kelompok PKK RT.001 RW.002 Kelurahan Dawuhan ini adalah :

1. Perlunya niat dan semangat untuk memulai usaha dan mengembangkannya khususnya produk pizza ini agar program peningkatan jiwa wirausaha menjadi terwujud dengan baik dan bisa menularkan pada anggota lainnya.

2. Untuk bisa mewujudkan menjadi seorang wirausahawan sejati, diperlukan kedisiplinan dan fleksibilitas dalam hal ide baru agar produk-produk yang dihasilkan mampu bersaing di pasar.

\section{DAFTAR PUSTAKA}

Abdullah, Maskur. 2005. Lilitan Masalah Usaha Mikro kecil, Menengah (UMKM) dan Kontroversi Kebijakan. Medan: Bitra Indonesia.

Anoraga, Panji. 2002. Koperasi, Kewirausahaan, dan Usaha Kecil. Jakarta: Rineka Cipta.

Departemen Perdagangan Republik Indonesia. 2008. Pengembangan Ekonomi Kreatif Indonesia 2025: Rencana Pengembangan Ekonomi Kreatif Indonesia 2009-2025. Jakarta: Departemen Perdagangan

Fuady, Munir, Pengantar Hukum Bisnis, (Bandung : PT.Citra Aditya Bakti, cetakan ke II, 2005)

https://cookpad.com/id/cari/pizza (diakses 24 Mei 2018)

https://selerasa.com/resep-dan-cara-membuat-pizza-italia-rumahan-sederhanatanpa-oven-namun-tetap-enak (diakses 24 Mei 2018)

Kotler, Philip, 2002, Manajemen Pemasaran, Jilid 2, Alih Bahasa oleh Hendra Teguh dkk, Edisi Milenium, Jakarta : PT Prenhallindo

Departemen Pendidikan Nasional. (2004). Pedoman Pengembangan Silabus di Taman Kanak-kanak. Jakarta: Depdiknas.

Chavem , (2017), http://cukupnurohmat.blogspot.co.id, Diakses pada 27 Agustus 2017 